Original scientific paper - Izvorni znanstveni rad

UDK: 637.075

\title{
Influence of milk product type and its initial contamination on the efficiency of different methods for detection of Salmonella Enteritidis, Listeria monocytogenes and Escherichia coli O157:H7
}

doi: 10.15567/mljekarstvo.2018.0101

\begin{abstract}
Boris Antunović ${ }^{*}$, Ivančica Kovaček ${ }^{2}$, Kristina Gvozdanović ${ }^{1}$, Manuela Grčević ${ }^{1}$, Vesna Gantner ${ }^{1}$, Vedran Poljak ${ }^{3}$, Mario Ostović ${ }^{4}, Z_{\text {Zeljko Pavičićc }}^{4}$, Nihada Ahmetovićs

${ }^{1}$ University of J.J. Strossmayer, Faculty of Agriculture, Department for Animal Husbandry, Vladimira Preloga 1, 31000 Osijek, Croatia

${ }^{2}$ Dr. Andrija Stampar Institute of Public Health, Department of Environmental Protection and Health Ecology, Division of Food and Consumer Goods Microbiology, Mirogojska cesta 16, 10000 Zagreb, Croatia

${ }^{3}$ Croatian Institute of Public Health, Department of Health Ecology, Rockefellerova 7, 10000 Zagreb, Croatia

${ }^{4}$ University of Zagreb, Faculty of Veterinary Medicine, Department of Animal Hygiene, Behaviour and Welfare, Heinzelova 55, 10000 Zagreb, Croatia ${ }^{5}$ University of Tuzla, Faculty of Medicine, Univerzitetska 1, Tuzla 75000, Bosnia and Herzegovina
\end{abstract}

Received - Prispjelo: 12.07.2017. Accepted - Prihvaćeno: 17.12.2017.

\begin{abstract}
This paper investigates differences in efficacy of isolating pathogenic bacteria Salmonella Enteritidis, Listeria monocytogenes and Escherichia coli O157:H7 between conventional cultivation (ISO method) and immunomagnetic separation (IMS method) related to the types of dairy products and initial numbers of bacteria. Different milk products (dairy pudding- vanilla or chocolate; a mixture of yoghurt and pudding; solid, liquid and fruit yoghurt; $A B$ culture - with or without fruit; cheese spread) were intentionally contaminated with different numbers $(\approx 10$ and $\approx 30)$ of live cells of the observed bacteria per $\mathrm{mL}$. The obtained results showed that the classical ISO procedure still represents an equally adequate method for the detection of $S$. Enteritidis and L. monocytogenes in dairy products as well as the IMS method. However, the ISO method was found to be inefficient for determination of $E$. coli $\mathrm{O} 157: \mathrm{H} 7$ when the initial contamination was low ( $\approx 10$ live cells per $\mathrm{mL}$ ). In such cases, even the IMS method appeared to be inefficient when used for fermented dairy products analysis. Fermented dairy products in contrast to the non-fermented ones, still represent a challenge for the development of routine detection methods, especially for $S$. Enteritidis, whilst the detection of L. monocytogenes and E. coli O157:H7 has improved by introducing the IMS method. The largest difference in the ability to detect bacteria in dairy product samples with reference to the initial number of bacteria by both methods was in the detection of E. coli O157:H7. The choice of broth (non-selective fluid broth vs. selective fluid broth) did not matter in the in the detection of $S$. Enteritidis and L. monocytogenes by applying the IMS procedure. However, for the detection of E. coli $\mathrm{O} 157: \mathrm{H} 7$ the application of modified tripton-soya broth with novobiocin (mTSB $+\mathrm{Nb}$ ) has proved to be superior when compared to using the buffered peptone water (BPW). The presented results may be of importance as a scientific basis for future determination of standard methods related to laboratory detection of pathogens in dairy products.
\end{abstract}

Key words: milk, dairy products, Salmonella Enteritidis, Listeria monocytogenes, Escherichia coli O157:H7, immunomagnetic separation

*Corresponding author/Dopisni autor: E-mail: Boris.Antunovic@pfos.hr 


\section{Introduction}

Milk, as an extraordinarily nutritious food, is an aqueous solution of protein, fat and carbohydrates, containing a large number of vitamins and minerals. Due to its high water content, almost neutral $\mathrm{pH}$ and nutrient richness, it is an ideal basis for growth and transmission of bacteria, especially pathogenic bacteria. Good microbiological quality of fresh raw milk is a prerequisite for good microbiological quality of milk and dairy products intended for consumption. In addition, bacterial contamination of milk can significantly increase the total number of microorganisms in milk and thus reduce its quality.

In food microbiology, the term "food safe for consumption" implies that it does not contain pathogenic bacteria, or it does contain them only to the extent that cannot cause health problems in humans. The pathogenic bacteria in food are mainly determined by qualitative methods to prove their presence in a given sample mass. Since no large number of pathogenic bacteria is expected in food, isolation methods are based on inoculating the specimens into different liquid broths that allow recovery and cultivation of sub-lethally damaged bacteria, followed by inoculation onto solid substrates (Reinders et al., 2003), after which bacteria still have to be confirmed biochemically and/or serologically. Such a method of isolation requires large amounts of different broths and is time-consuming, hence the aim is to find faster, more effective and more sensitive methods for isolation and identification of pathogenic bacteria, which will produce results about the microbiological safety of food in a short time.

Immunomagnetic separation (IMS) is a method of concentration and separation of microorganisms based on the specific binding of bacteria to microscopic, magnetized beads with adsorbed antibodies. This results in selective concentration of targeted bacteria in the investigated sample. The method is a substitute for a standard cultivation of bacteria and is relatively inexpensive, fast and easy to use (Kohn, 2000). When performing the IMS method, polystyrene beads are used, the surfaces of which are magnetized and hydrophobic, allowing binding of different molecules. The advantage of the magnetized surface is reflected in the magnetic field under which the pellets are collected at the nearest point to the magnet. Outside the magnetic field, pellets are easily dispersed into a homogeneous suspension (Fratamico and Crawford, 2000; Park et al., 2013; He et al., 2014).

The aim of this paper was to investigate differences in efficacy of isolating pathogenic bacterial strains of Salmonella Enteritidis, Listeria monocytogenes and Escherichia coli O157:H7 between the conventional ISO procedure and immunomagnetic separation (IMS) in relation to the different types of dairy products and initial numbers of bacteria.

\section{Materials and methods}

The study included bacterial cultures of Salmonella Enteritidis ATCC strain 13076, Listeria monocytogenes ATCC strain 7644 and Escherichia coli O157: H7 serotype 35150, purchased from the Oxoid Ltd. company as Culti-Loops ${ }^{\circledR}$. The samples of following dairy products were examined: dairy pudding (vanilla, chocolate); a mixture of yoghurt and pudding; solid, liquid and fruit yoghurt; $A B$ culture (with and without fruit); cheese spread. Sampling and sample preparation were carried out according to the standard recommendations (British Standard BS 4285, 1993). As a control procedure, each sample was examined in parallel triplicates in order to confirm the same density of bacterial colonies each time of testing the same sample.

Using a densitometer, three bacterial suspensions were prepared in a saline solution containing approximately $3.0 \times 10^{8}$ bacterial cells $(S$. Enteritidis, L. monocytogenes or E. coli O157:H7). Subsequently, two decimal dilutions of each of the basic bacterial suspensions were prepared with saline $\left(3 \times 10^{3} \mathrm{CFU} / \mathrm{mL}\right.$ and $\left.10^{3} \mathrm{CFU} / \mathrm{mL}\right)$. For the purpose of intentional contamination, $1 \mathrm{~mL}$ of selected decimal dilution $\left(3 \times 10^{3} \mathrm{CFU} / \mathrm{mL}\right.$, or $\left.10^{3} \mathrm{CFU} / \mathrm{mL}\right)$ was added to $100 \mathrm{~mL}$ of each investigated sample of the milk product, resulting with $\approx 10$ or $\approx 30$ live bacteria cells (S. Enteritidis, L. monocytogenes or E. coli $\mathrm{O} 157: \mathrm{H7}$ ) per $\mathrm{mL}$ of each sample, respectively. Subsequently, samples were homogenized and incubated for 24 hours at $37^{\circ} \mathrm{C}$. Isolation of the bacteria was performed by the classical isolation procedure and by the IMS. The procedure was carried out using a non-selective fluid broth for cultivation in 
buffering peptone water (BPW) and selective fluid broth for cultivation as follows; for Salmonella Enteritidis Rappaport-Vassiliadis (RV), for Listeria monocytogenes Half Fraser, and for Escherichia coli O157: H7 modified tripton soya broth with novobiocin $(\mathrm{m}-\mathrm{TSB}+\mathrm{Nb})$. For the control, in triplicate, the same samples of milk and milk products were prepared with $1 \mathrm{~mL}$ of saline solution, then homogenized, incubated for 24 hours at $37^{\circ} \mathrm{C}$. Isolation of Salmonella Enteritidis was performed according to the international standard ISO 6579: 2002, Listeria monocytogenes according to the international standard ISO 10560: 1993, BS 4285: 1993, and isolation of Escherichia coli O157: H7 according to the method described by Batt (2000).

The IMS isolation method of these bacteria was performed as follows. Microencentrifugation tubes were punctured with $20 \mu \mathrm{L}$ of Dynabeads (Dynal) pellets with adsorbed antibodies of selected bacteria and $1 \mathrm{~mL}$ suspension of the investigated sample was incubated for 24 hours in broth for cultivation. The contents of the test tubes were lightly mixed on a rotary mixer at a rate of about $12 \mathrm{x}$ per minute at room temperature for 3 minutes. After that, the tubes were removed from the mixer and a magnet was placed on them for a period of 1-3 minutes. The magnet served to attract the material that was attached to the Dynabeads pellets onto the walls of the test tubes. The liquid part was carefully separated and the pellet-bearing material was retained on the wall by the magnetic field. Afterwards $1 \mathrm{~mL}$ of PBS-Tween flushing buffer was added to the tubes. The procedure was repeated 2-4 times, depending on the time required for the pellet-bound bacteria to rinse off the excess. In the final step, $100 \mu \mathrm{L}$ of PBS-Tween flushing buffer was added to each of the tubes and the contents of the tubes were homogenized. After the IMS procedure, $50 \mu \mathrm{L}$ of Dynabeads bacterial complex was inoculated onto solid broth.

Table 1. Comparison of density of Salmonella Enteritidis colonies isolated by different methods from samples of investigated dairy products after intentional contamination with $\approx 10$ and $\approx 30$ live bacterial cells per $\mathrm{mL}$

\begin{tabular}{|c|c|c|c|c|c|c|}
\hline \multirow[b]{3}{*}{ Sample } & \multicolumn{3}{|c|}{$\begin{array}{l}\text { Intentional inoculation with } \approx 10 \text { live cells } \\
\text { of } S \text {. Enteritidis per } \mathrm{mL}\end{array}$} & \multicolumn{3}{|c|}{$\begin{array}{l}\text { Intentional inoculation with } \approx 30 \text { live cells } \\
\text { of } S \text {. Enteritidis per } \mathrm{mL}\end{array}$} \\
\hline & \multicolumn{6}{|c|}{ Isolation method } \\
\hline & $\begin{array}{l}\text { Classical } \\
\text { ISO } \\
\text { procedure }\end{array}$ & $\begin{array}{c}\text { IMS on } \\
\text { non-selective } \\
\text { fluid broth (BPW) }\end{array}$ & $\begin{array}{c}\text { IMS on } \\
\text { selective fluid } \\
\text { broth (RV) }\end{array}$ & $\begin{array}{l}\text { Classical } \\
\text { ISO } \\
\text { procedure }\end{array}$ & $\begin{array}{c}\text { IMS on } \\
\text { non-selective } \\
\text { fluid broth (BPW) }\end{array}$ & $\begin{array}{c}\text { IMS on } \\
\text { selective fluid } \\
\text { broth (RV) }\end{array}$ \\
\hline $\begin{array}{l}\text { Dairy pudding } \\
\text { (vanilla) }\end{array}$ & $4+$ & $4+$ & $4+$ & $4+$ & $4+$ & $4+$ \\
\hline $\begin{array}{l}\text { Dairy pudding } \\
\text { (chocolate) }\end{array}$ & $4+$ & $4+$ & $4+$ & $4+$ & $4+$ & $4+$ \\
\hline Yoghurt + pudding & $2+$ & $1+$ & $1+$ & $3+$ & $1+$ & $1+$ \\
\hline Solid yoghurt & 0 & 0 & 0 & 0 & 0 & 0 \\
\hline Liquid yoghurt & 0 & 0 & 0 & 0 & 0 & 0 \\
\hline Fruit yoghurt & 0 & 0 & 0 & $2+$ & $1+$ & $1+$ \\
\hline $\mathrm{AB}$ culture & 0 & 0 & 0 & 0 & 0 & 0 \\
\hline $\begin{array}{l}\text { AB culture } \\
\text { (with fruit) }\end{array}$ & 0 & 0 & 0 & $1+$ & $1+$ & $1+$ \\
\hline Cheese spread & $1+$ & $1+$ & $1+$ & $3+$ & $2+$ & $2+$ \\
\hline
\end{tabular}

Density of bacterial colonies: $(0)=$ no colonies growth; $(1+)=1-100$ colonies; $(2+)=101$-1000 colonies; $(3+)=>1000$ colonies; $(4+)=$ fused colonies

IMS - immunomagnetic separation; BPW - buffered peptone water; RV - Rappaport-Vassiliadis broth

Note: As an internal check, each sample was examined in parallel triplicates in order to confirm the same density of bacterial colonies each time of testing the same sample 


\section{Results and discussion}

The obtained results revealed differences in the efficacy of different methods of isolation of pathogenic bacteria $S$. Enteritidis, L. monocytogenes and $E$. coli $\mathrm{O} 157: \mathrm{H7}$ from dairy product samples that were intentionally contaminated with lower $(\approx 10)$ and higher $(\approx 30)$ numbers of live bacterial cells per $\mathrm{mL}$.

As shown in Table 1, the number of colonies of $S$. Enteritidis increased to the greatest extent in samples of dairy puddings, from which they were easily isolated by all investigated methods, even when there was little initial contamination, so with $\approx 10$ living bacterial cells $\mathrm{mL}$.

After smaller and larger initial contamination, S. Enteritidis was successfully extracted from a mixture of yoghurt and pudding, and from cheese spread, indicating that these products being a good media for its growth and reproduction. After 24 hours' incubation, $S$. Enteritidis was not isolated at all from solid and liquid yoghurt, or from $\mathrm{AB}$ culture, while from fruit yoghurt and fruit $A B$ culture it was extracted only at higher initial contamination levels of samples $(\approx 30$ live bacterial cells per $\mathrm{mL})$. The obtained results were in agreement with the results of Nissen and Holck (1998), who explained the small number of $S$. Kentucky bacteria in fermented cured meat products by the action of bacteriocine derived from lactic acid bacteria. Porto-Fett et al. (2008), and Hwang et al. (2009) also confirmed that fermentation and drying, i.e. low $\mathrm{pH}$ value and water activity, as well as growth of competitive microorganisms (lactic acid bacteria), reduce the number of Salmonella bacteria in fermented sausages. As quoted by Odumer and León-Velarde (2012), methods based on isolation of bacteria by nutrient broths are still most widely used and represent the standard for detection of bacteria from Salmonella genus due to their selectivity and sensitivity. Özer and Kimiran-Erdem (2013) have proved that the classical ISO method of growing bacteria was more sensitive than the IMS method for determining the presence of bacteria of the Salmonella genus in meat samples. Similarly, Eriksson and Aspan (2007)

Table 2. Comparison of density of Listeria monocytogenes colonies isolated by different methods from samples of investigated dairy products after intentional contamination with $\approx 10$ and $\approx 30$ live bacterial cells per $\mathrm{mL}$

\begin{tabular}{|c|c|c|c|c|c|c|}
\hline & \multicolumn{3}{|c|}{$\begin{array}{l}\text { Intentional inoculation with } \approx 10 \text { live cells } \\
\text { of } L \text {. monocytogenes per } \mathrm{mL}\end{array}$} & \multicolumn{3}{|c|}{$\begin{array}{l}\text { Intentional inoculation with } \approx 30 \text { live cells } \\
\text { of } L \text {. monocytogenes per } \mathrm{mL}\end{array}$} \\
\hline & \multicolumn{6}{|c|}{ Isolation method } \\
\hline Sample & $\begin{array}{l}\text { Classical } \\
\text { ISO } \\
\text { procedure }\end{array}$ & $\begin{array}{c}\text { IMS on } \\
\text { non-selective } \\
\text { fluid broth (BPW) }\end{array}$ & $\begin{array}{l}\text { IMS on selec- } \\
\text { tive fluid broth } \\
\text { (Fraser broth) }\end{array}$ & $\begin{array}{l}\text { Classical } \\
\text { ISO } \\
\text { procedure }\end{array}$ & $\begin{array}{c}\text { IMS on } \\
\text { non-selective } \\
\text { fluid broth (BPW) }\end{array}$ & $\begin{array}{l}\text { IMS on selec- } \\
\text { tive fluid broth } \\
\text { (Fraser broth) }\end{array}$ \\
\hline $\begin{array}{l}\text { Dairy pudding } \\
\text { (vanilla) }\end{array}$ & $2+$ & $2+$ & $2+$ & $2+$ & $2+$ & $1+$ \\
\hline $\begin{array}{l}\text { Dairy pudding } \\
\text { (chocolate) }\end{array}$ & $2+$ & $2+$ & $2+$ & $2+$ & $2+$ & $1+$ \\
\hline $\begin{array}{l}\text { Yoghurt }+ \\
\text { pudding }\end{array}$ & $1+$ & $1+$ & $1+$ & $2+$ & $1+$ & $1+$ \\
\hline Solid yoghurt & 0 & 0 & 0 & $1+$ & $1+$ & $1+$ \\
\hline Liquid yoghurt & 0 & 0 & 0 & $1+$ & $1+$ & $1+$ \\
\hline Fruit yoghurt & 0 & 0 & 0 & $2+$ & $1+$ & $1+$ \\
\hline $\mathrm{AB}$ culture & 0 & 0 & 0 & 0 & $1+$ & $1+$ \\
\hline $\begin{array}{l}\text { AB culture } \\
\text { (with fruit) }\end{array}$ & 0 & 0 & 0 & $1+$ & $1+$ & $1+$ \\
\hline Cheese spread & $2+$ & 0 & 0 & $2+$ & $1+$ & $1+$ \\
\hline
\end{tabular}

Density of bacterial colonies: $(0)=$ no colonies growth; $(1+)=1-100$ colonies; $(2+)=101-1000$ colonies;

$(3+)=>1000$ colonies; $(4+)=$ fused colonies

IMS - immunomagnetic separation; BPW - buffered peptone water

Note: As an internal check, each sample was examined in parallel triplicates in order to confirm the same density of bacterial

colonies each time of testing the same sample 
found that the standard ISO procedure is the most reliable and most sensitive method for detecting different strains of Salmonella in faecal samples compared to other tested methods. Based on their results, the IMS method seems to be less sensitive for the isolation of certain strains of Salmonella, which has been linked with lower binding of antibodies present on magnetic pellets. However, according to our results, the IMS method, in most cases, had the same sensitivity for the detection of $S$. Enteritidis in dairy products as the traditional ISO procedure. The types of broths did not play a role in the efficiency of isolation, as the results were identical by usage of non-selective fluid broth (BPW) and selective fluid broth (RV).

Similarly, L. monocytogenes has also been successfully isolated by all the three methods from dairy pudding (vanilla and chocolate) and pudding with the addition of yoghurt at higher and lower initial levels of contamination (Table 2).
On contrary, L. monocytogenes colonies were isolated from fermented dairy products (solid yoghurt, liquid yoghurt, fruit yoghurt, $\mathrm{AB}$ culture and $\mathrm{AB}$ culture with fruit) only at higher initial contamination of the samples $(\approx 30$ live cells). Isolation from cheese spread was more successful by the classical ISO procedure, whilst IMS was found to be inefficient for lower initial contamination $(\approx 10$ live cells). These findings can be explained by a large number of live lactic acid bacteria in fermented dairy products and the growth of bacteriocin, which inhibits the reproduction of L. monocytogenes (Djenane et al., 2005, Liu et al., 2008). Wadud et al. (2010) compared the success of three different isolation and identification methods for L. monocytogenes in ready-toeat foods. The results of their research showed that IMS was equally sensitive as the traditional isolation method, but could be more favourable since it allows small number of bacteria to be identified after 18 to 24 hours, which reduces the volume of work

Table 3. Comparison of density of Escherichia coli O157:H7 colonies isolated by different methods from samples of investigated dairy products after intentional contamination with $\approx 10$ and $\approx 30$ live bacterial cells per $\mathrm{mL}$

\begin{tabular}{|c|c|c|c|c|c|c|}
\hline \multirow{3}{*}{ Sample } & \multicolumn{3}{|c|}{$\begin{array}{l}\text { Intentional inoculation with } \approx 10 \text { live cells } \\
\text { of } E \text {. coli } \mathrm{O} 157: \mathrm{H} 7 \text { per } \mathrm{mL}\end{array}$} & \multicolumn{3}{|c|}{$\begin{array}{l}\text { Intentional inoculation with } \approx 30 \text { live cells } \\
\text { of } E \text {. coli } \mathrm{O} 157: \mathrm{H} 7 \text { per } \mathrm{mL}\end{array}$} \\
\hline & \multicolumn{6}{|c|}{ Isolation method } \\
\hline & $\begin{array}{l}\text { Classical } \\
\text { ISO } \\
\text { procedure }\end{array}$ & $\begin{array}{c}\text { IMS on } \\
\text { non-selective } \\
\text { fluid broth (BPW) }\end{array}$ & $\begin{array}{l}\text { IMS on selec- } \\
\text { tive fluid broth } \\
(\mathrm{mTSB}+\mathrm{Nb})\end{array}$ & $\begin{array}{l}\text { Classical } \\
\text { ISO } \\
\text { procedure }\end{array}$ & $\begin{array}{c}\text { IMS on } \\
\text { non-selective } \\
\text { fluid broth (BPW) }\end{array}$ & $\begin{array}{l}\text { IMS on selec- } \\
\text { tive fluid broth } \\
(\mathrm{mTSB}+\mathrm{Nb})\end{array}$ \\
\hline $\begin{array}{l}\text { Dairy pudding } \\
\text { (vanilla) }\end{array}$ & 0 & $1+$ & $1+$ & $3+$ & $3+$ & $3+$ \\
\hline $\begin{array}{l}\text { Dairy pudding } \\
\text { (chocolate) }\end{array}$ & 0 & $1+$ & $1+$ & $3+$ & $3+$ & $3+$ \\
\hline $\begin{array}{l}\text { Yoghurt }+ \\
\text { pudding }\end{array}$ & 0 & $1+$ & $1+$ & $1+$ & $1+$ & $2+$ \\
\hline Solid yoghurt & 0 & 0 & 0 & 0 & $1+$ & $2+$ \\
\hline Liquid yoghurt & 0 & 0 & 0 & 0 & $1+$ & $2+$ \\
\hline Fruit yoghurt & 0 & 0 & $1+$ & $1+$ & $1+$ & $2+$ \\
\hline $\mathrm{AB}$ culture & 0 & 0 & 0 & 0 & $1+$ & $2+$ \\
\hline $\begin{array}{l}\text { AB culture } \\
\text { with fruit }\end{array}$ & 0 & 0 & 0 & 0 & $1+$ & $2+$ \\
\hline Cheese spread & 0 & 0 & $1+$ & $1+$ & $1+$ & $2+$ \\
\hline
\end{tabular}

Density of bacterial colonies: $(0)=$ no colonies growth; $(1+)=1-100$ colonies; $(2+)=101-1000$ colonies;

$(3+)=>1000$ colonies; $(4+)=$ fused colonies

IMS - immunomagnetic separation; BPW - buffered peptone water

$\mathrm{mTSB}+\mathrm{Nb}$ - modified tripton-soya broth with novobiocin

Note: As an internal check, each sample was examined in parallel triplicates in order to confirm the same density of

bacterial colonies each time of testing the same sample 
and time needed to determine the presence of bacteria in the samples. The same has been confirmed by results of the present research, except for the cheese spread with low initial contamination. Nonselective broths (BPW) were slightly more efficient than non-selective fluid broths (BPW) in the case of IMS applied to the pudding samples.

Regarding the E. coli O157:H7 isolation, in the cases of higher initial sample contamination $(\approx 30$ live cells), it was successfully isolated by the usage of all the methods and broths from dairy pudding, yoghurt with pudding, fruit yoghurt and cheese spread. However, there was no success in isolation of this bacteria by standard ISO procedure from fermented products (solid yoghurt, liquid yogurt, $\mathrm{AB}$ culture, $\mathrm{AB}$ culture with fruit) (Table 3).

At higher initial contamination of the samples, the best isolation method was IMS, preceded by the cultivation in selective liquid broth with MTSB and novobiocin added, except for dairy puddings, where all the observed methods were equally effective in the isolation of E. coli O157:H7. In case of minor bacterial contamination $(\approx 10$ live cells), E. coli $\mathrm{O} 157: \mathrm{H} 7$ was not isolated by ISO method from none of the investigated dairy products, whilst IMS method was successful in extraction from dairy pudding, yoghurt with pudding, fruit yoghurt and cheese spread (the latest two only on selective fluid broth $\mathrm{mTSB}+\mathrm{Nb}$ ). In general, the most sensitive method, same as it was at the higher bacterial contamination, was the IMS method after multiplication in selective liquid broth mTSB with novobiocin. This is in accordance with Saab Khudhir (2013), who investigated the effectiveness of IMS and conventional isolation methods for isolation of E. coli from samples of fresh milk and soft cheese. Their results showed that IMS method was significantly more efficient and more sensitive method for detecting small number of $E$. coli than the conventional inoculation method on solid substrates, which was consistent with our results.

The E. coli $\mathrm{O} 157: \mathrm{H} 7$ was isolated in all samples intentionally contaminated with $\approx 30$ live bacterial cells/mL by IMS method, suggesting that this strain may survive under unfavourable conditions, such as the presence of lactic acid bacteria (Nissen and Holck, 1998; Lahti et al., 2001). E. coli O157: $\mathrm{H} 7$ is obviously able to survive very low $\mathrm{pH}$ values, such as in stomach conditions $(\mathrm{pH}=1-2)$, and has been shown to utilize various mechanisms to adapt to acidic stress (Richard and Foster, 2003; Stincone et al., 2011; Kanjee and Houry, 2013). In the presented results, the difference in the density of bacterial colony growth was more obvious after contamination of dairy products with small number $(\approx 10)$ of live bacteria E. coli O157. The IMS method carried out with the addition of novobiocin in the selective liquid medium of mTSB enabled successful isolation of E. coli O157:H7 from products with smaller initial number of bacteria ( $\approx 10$ live cells) such as dairy puddings, yoghurt with pudding, fruit yoghurt and cheese spread. After carrying out the IMS method with the prior cultivation in nonselective liquid broth, i.e. BPW and low initial contamination $(\approx 10$ live cells), E. coli O157:H7 was successfully isolated only from dairy puddings and yoghurts with pudding, and was not isolated by traditional ISO method, at all.

The presented results suggest that such a small initial concentration as $\approx 10$ live cells could be well detectable at the same level as the initial concentration of $\approx 30$ live cells in the cases of contamination of non-fermented products (dairy puddings) by $S$. Enteritidis and L. monocytogenes (Tables 1 and 2). The detectability was especially efficient for detection of $S$. Enteritidis in pudding, as all the colonies were even fused after both initial bacterial concentrations $(\approx 10$ and $\approx 30$ live cells, Table 1$)$. In contrast to that, we found obvious differences for E. coli O157:H7 detection depending on initial contamination, with no colony growth detected, or 1-100 colonies detected, after initial contamination with $\approx 10$ live cells using classical ISO procedure, or IMS procedure (both on selective and non-selective broths; BPW and $\mathrm{mTSB}+\mathrm{Nb}$ ), respectively. At the same time, the intentional inoculation by $\approx 30$ live cells of E. coli O157:H7 resulted in > 1000 colonies detected both by classical ISO procedure, or IMS procedure (both on selective and non-selective broths; $\mathrm{BPW}$ and $\mathrm{mTSB}+\mathrm{Nb}$ ). Lower growth rate of $E$. coli O157:H7 after inoculation by such a small concentration as $\approx 10$ live cells compared to $\approx 30$ live cells, as well as compared to the growth rates of $S$. Enteritidis and $L$. monocytogenes, is in accordance with the results of Kim and Bhunia (2008). They found 
no growth of E. coli O157:H7 inoculated by $\approx 10$ live cells into $\mathrm{mEC}+\mathrm{n}$ (modified $E$. coli broth with $20 \mathrm{mg}$ of novobiocin/L), whilst the same level of intentional contamination was detectable in the cases of $S$. Enteritidis and L. monocytogenes (on respective broths), where the small level of initial contamination did not play such important role. According to the same authors, the initial contamination by $\approx 30$ live cells was sufficient for growth and detection for all of the examined bacterial strains.

Apart from the initial contamination, the type of the broth used for the IMS methods in detection of E. coli O157:H7 plays the role in sensitivity, as well, which is in favour of using selective fluid broth $(\mathrm{mTSB}+\mathrm{Nb})$.

\section{Conclusions}

The classical ISO procedure still represents an equally adequate method for detection of $S$. Enteritidis and L. monocytogenes in dairy products as the IMS method. However, the ISO method was found to be inefficient for determination of $E$. coli O157:H7 at low initial contamination $(\approx 10$ live cells per $\mathrm{mL}$ ). In such cases, even the IMS method appeared to be inefficient when used on fermented dairy products. Fermented dairy products still represent a challenge for development of routine detection methods, especially for $S$. Enteritidis, whilst the detection of $L$. monocytogenes and E. coli O157:H7 has improved by the introduction of the IMS method. The largest difference in the ability to detect bacteria in dairy product samples related to the initial number of bacteria by both methods was observed in the detection of E. coli O157:H7. Whilst choice of broth (non-selective fluid broth vs. selective fluid broth) did not matter for applying the IMS procedure in the detection of $S$. Enteritidis and $L$. monocytogenes, in the cases of detection of E. coli O157:H7 the usage of modified tripton-soya broth with novobiocin $(\mathrm{mTSB}+\mathrm{Nb})$ has proved to be superior compared to the usage of buffered peptone water (BPW). The above results may be of importance as a scientific basis for future determination of standard methods related to laboratory detection of important pathogens in dairy products.
Utjecaj vrste mliječnih proizvoda i početne kontaminacije na učinkovitost različitih metoda dokazivanja bakterija Salmonella Enteritidis, Listeria monocytogenes $i$ Escherichia coli O157:H7

\section{Sažetak}

$\mathrm{U}$ radu se istražuju razlike $\mathrm{u}$ učinkovitosti dokazivanja patogenih bakterija Salmonella Enteritidis, Listeria monocytogenes i Escherichia coli O157:H7 između konvencionalne kultivacije bakterija (ISO metoda) i imunomagnetne separacije (IMS metoda) u različitim vrstama mliječnih proizvoda s inicijalnim brojem bakterija. Različiti uzorci mliječnih proizvoda (mliječni puding - vanilija ili čokolada; mješavina jogurta i pudinga; čvrsti, tekući i voćni jogurt, $A B$ kultura - sa ili bez voća; sirni namaz) namjerno su kontaminirani različitim brojem istraživanih bakterija $(\approx 10$ i $\approx 30$ živih stanica po $\mathrm{mL}$ ). Klasični ISO postupak pokazao se jednako adekvatnom metodom za uporabu u svrhu otkrivanja $S$. Enteritidis i L. monocytogenes u mliječnim proizvodima kao i IMS metoda. Međutim, ISO postupak pokazao se neučinkovitim za dokazivanje E. coli $\mathrm{O} 157: \mathrm{H} 7 \mathrm{u}$ slučajevima kada je početna kontaminacija bila niska $(\approx 10$ živih stanica po $\mathrm{mL}$ ). U takvim slučajevima IMS metoda nije bila učinkovita niti na fermentiranim mliječnim proizvodima. Nasuprot nefermentiranim mliječnim proizvodima, fermentirani proizvodi još uvijek predstavljaju izazov za razvoj rutinske metode detekcije, osobito za $S$. Enteritidis, dok je detekcija L. monocytogenes i E. coli O157: H7 poboljšana uvođenjem IMS metode. Najveća razlika u efikasnosti dokazivanja patogenih bakterija u uzorcima mliječnih proizvoda, povezana s niskim početnim brojem bakterija u uzorku, pokazala se pri detekciji E. coli O157:H7. Dok izbor hranjive podloge (neselektivna tekuća hranjiva podloga, nasuprot selektivnoj tekućoj hranjivoj podlozi) ne igra važnu ulogu u primjeni IMS postupka pri otkrivanju $S$. Enteritidis i L. monocytogenes. U slučajevima dokazivanja E. coli O157:H7, uporaba modificiranog tripton-sojinog bujona s novobiocinom (mTSB $+\mathrm{Nb})$ pokazala se učinkovitijom u usporedbi s uporabom puferirane peptonske vode (PPV). Dobiveni rezultati mogu 
biti od značaja kao znanstvena osnova za buduće određivanje standardnih metoda vezanih za laboratorijsko otkrivanje važnih patogena u mliječnim proizvodima.

Ključne riječi: mlijeko, mliječni proizvodi, Salmonella Enteritidis, Listeria monocytogenes, Escherichia coli O157: H7, imunomagnetna separacija

\section{References}

1. Batt, C.A. (2000): Escherichia coli. In: Encyclopedia of Food Microbiology (Robinson R.K., Batt, C.A. and Patel, P.D., Ed.). Academic Press. A Harcourt Science and Technology Company, London, UK., Vol. 1, 633-640.

2. British standard BS 4285:1993: Microbiological examination for dairy purposes. Section 3.15. Detection of Listeria monocytogenes. British Standards Institution, London, UK.

3. Djenane, D., Martínez, L., Blanco, D., Yangüela, J., Beltrán, J.A., Roncalés, P. (2005): Effect of lactic acid bacteria on extension of shelf life and growth of Listeria monocytogenes in beef steaks stored in $\mathrm{CO}_{2}$-rich atmosphere. Brazilian Journal of Microbiology 36, 405-412. https://doi.org/10.1590/S1517-83822005000400018

4. Eriksson, E., Aspan, A (2007): Comparison of culture, ELISA and PCR techniques for Salmonella detection in faecal samples for cattle, pig and poultry. BMC Veterinary Research, 3, 21. https://doi.org/10.1186/1746-6148-3-21

5. Fratamico, P.M., Crawford, C.G. (2000): Detection by Commercial Immunomagnetic Particle-based Assays. In: Encyclopedia of Food Microbiology (Robinson, R.K., Batt, C.A. and Patel, P.D., Ed.), Academic Press. A Harcourt Science and Technology Company, London. Vol. $1,654-661$.

6. He, J., Huang, M., Wang, D., Zhang, Z., Li, L. (2014): Magnetic separation techniques in sample preparation for biological analysis: A review. Journal of Pharmaceutical and Biomedical Analysis 101, 84-101. https://doi.org/10.1016/j.jpba.2014.04.017

7. Hrvatska norma HRN ISO 6579:2003, Mikrobiologija hrane i stočne hrane - Horizontalna metoda za otkrivanje Salmonella spp. (ISO 6579: 2002)

8. Hwang, C.A., Porto-Fett, A.C., Juneja, V.K., Ingham, S.C., Ingham, B.H., Luchansky, J.B. (2009): Modelling the survival of Escherichia coli O157:H7, Listeria monocytogenes and Salmonella typhimurium during fermentation, drying and storage of soudjouk-style fermented sausage. International Journal of Food Microbiology 129 (3), 244-252. https://doi.org/10.1016/j.ijfoodmicro.2008.12.003
9. International Standard ISO 10560:1993: Milk and milk products - Detection of Listeria monocytogenes.

10. Kanjee, U., Houry, W.A. (2013): Mechanisms of acid resistance in Escherichia coli. Annual Review of Microbiology 67, 65-81. https://doi.org/10.1146/annurev-micro-092412-155708

11. Kim, H., Bhunia, A.K. (2008): SEL, a selective enrichment broth for simultaneous growth of Salmonella enterica, Escherichia coli O157:H7, and Listeria monocytogenes. Applied Environmental Microbiology 74 (15), 4853-4866. https://doi.org/10.1128/AEM.02756-07

12. Kohn, B. (2000): Detection by commercial immunomagnetic particle-based assays. In: Encyclopedia of Food Microbiology (Robinson, R.K., Batt, C.A. and Patel, P.D., Ed.) Academic Press. A Harcourt Science and Technology Company, London. Vol. 2, 1222-1228.

13. Lahti, E., Johansson, T., Honkanen-Buzalski, T., Hill, P., Nurmi, E. (2001): Survival and detection of Escherichia coli $\mathrm{O} 157: \mathrm{H} 7$ and Listeria monocytogenes during the manufacture of dry sausage using two different starter cultures. Food Microbiology 18, 75-85. https://doi.org/10.1006/fmic.2000.0373

14. Liu, L., O'Conner, P., Cotter, P.D., Hill, C., Ross, R.P. (2008): Controlling Listeria monocytogenesin Cottage cheese through heterologous production of enterocin A by Lactococcus lactis. Journal of Applied Microbiology 104, 1059-1066. https://doi.org/10.1111/j.1365-2672.2007.03640.x

15. Nissen, H., Holck, A. (1998): Survival of Escherichia coli $\mathrm{O} 157: \mathrm{H7}$, Listeria monocytogenes and Salmonella kentucky in Norwegian fermented, dry sausage. Food Microbiology 15, 273-279. https://doi.org/10.1006/fmic.1997.0165

16. Odumeru, J.A., León-Velarde, C.G. (2012): Salmonella detection methods for food and food ingredients, Salmonella - A dangerous foodborne pathogen (Barakat, S., Mahmoud, M., Ed.), InTechOpen, 373-393. https:// www.intechopen.com/books/salmonella-a-dangerousfoodborne-pathogen/salmonella-detection-methodsfor-food-and-food-ingredients (30.06.2017.)

17. Özer, D., Kimiran-Erdem, A. (2013): Comparison of different methods for the detection of Salmonella spp. in minced meat samples. Kafkas Üniversitesi Veterinerlik Fakültesi Dergisi, 19(5), 801-806.

18. Park, H., Hwang, M.P., Lee, K.H. (2013): Immunomagnetic nanoparticle-based assays for detection of biomarkers. International Journal of Nanomedicine 8, 4543-4552.

19. Porto-Fett, A.C., Hwang, A.C.., Call, J.E., Juneja, V.K., Ingham, S.C., Ingham, B.H. Luchansky, J.B. (2008): Viability of multi-strain mixtures of Listeria monocytogenes, Salmonella typhimurium or Escherichia coli O157:H7 inoculated into the batter or onto the surface of a soudjouk-style fermented semi-dry sausage. Food Microbiology 25(6), 793-801. https://doi.org/10.1016/j.fm.2008.04.012 
20. Reinders, R.D., Jonge, R.D., Evers, E.G. (2003): A statistical method to determine whether microorganisms are randomly distributed in food matrix, applied to coliforms and Escherichia coli $\mathrm{O} 157$ in minced beef. Food Microbiology 20, 297-303. https://doi.org/10.1016/S0740-0020(02)00134-X

21. Richard, H.T., Foster, J.W. (2003): Acid resistance in Escherichia coli. Advances in Applied Microbiology 52, 167-186. https://doi.org/10.1016/S0065-2164(03)01007-4

22. Saab Khudhir, Z. (2013): Immunomagnatic separation of E.coli O157:H7 from raw milk and locally produced soft cheese in Baghdad City. The Iraqi Journal of Veterinary Medicine 37(1), 35-39.
23. Stincone, A., Daudi, N., Rahman, A.S., Antczak, P., Henderson, I., Cole, J., Johnson, M.D., Lund, P., Falciani, F. (2011): A systems biology approach sheds new light on Escherichia coli acid resistance. Nucleic Acids Research 39, 7512-7528. https://doi.org/10.1093/nar/gkr338

24. Wadud, S., Leon-Velarde, C.G., Larson, N., Odumeru, J.A. (2010): Evaluation of immunomagnetic separation in combination with ALOA Listeria chromogenic agar for the isolation and identification of Listeria monocytogenes in ready-to-eat foods. Journal of Microbiological Methods 81, 153-159. https://doi.org/10.1016/j.mimet.2010.02.014 